\title{
Hydrochemical characteristics of the groundwaters in Prilep's part of Pelagonia Valley - Republic of Macedonia
}

The Mining-Geology-Petroleum Engineering Bulletin UDC: 556.3

DOI: $10.17794 / \operatorname{rgn} .2018 \cdot 3 \cdot 11$

Original scientific paper

\author{
${ }^{1}$ Vojo Mirčovski, ${ }^{2}$ Biljana Gičevski, 'Gorgi Dimov \\ ${ }^{1}$ Faculty of Natural and Technical Sciences, Institute of Geology, “Goce Delcev” University in Stip Blvd. Goce Delcev 89, 2000 Stip, \\ Republic of Macedonia. \\ ${ }^{2}$ Exploring Society "Ursusspeleos”, Dobromir Hrs 20 a, 1000 Skopje, Republic of Macedonia.
}

\begin{abstract}
This paper presents the results of hydrochemical investigations of groundwater from the Prilep part of Pelagonia Valley - Republic of Macedonia. These investigations were carried out by analysing 12 samples of groundwater, taken from exploitation wells. Samples were taken once, during August 2013. The values of $\mathrm{pH}$ were determined with a field digital $\mathrm{pH}$ meter, while cations were determined by inductively coupled plasma-atomic emission spectrometry (ICP - AES). For the determination of anions standard EPA methods were used (gravimetric - TDS, volumetric - $\mathrm{Cl}^{-}$, spectrophotometric - $\mathrm{NO}_{3}^{-}, \mathrm{NO}_{2}^{-}, \mathrm{NH}^{4+}$ and turbidimetric - $\mathrm{SO}_{4}^{2-}$ with the spectrophotometer $6715 \mathrm{UV} / \mathrm{VIS}$, Jenway). Maps with spatial distribution of the hydrochemical components were prepared using the IDW (Inverse Distance Weighting) method for map generation (Geographic Information System software (GIS) ESRI ${ }^{\circledR}$ ArcGis $^{\mathrm{TM}}$ 9.2 and its extension Geostatistical Analyst). Graphical methods, Piper diagram and Chadha's diagram, were applied in order to determine the hydrochemical properties of the groundwater. The results indicate that the groundwater samples have different hydrochemical properties. Ca ${ }^{2+}>\mathrm{Na}^{+}>\mathrm{Mg}^{2+}$ for the cations and $\mathrm{HCO}_{3}>\mathrm{Cl}^{-}>\mathrm{SO}_{4}{ }^{2-}$ for the anions were dominantly dissolved ions in the majority of the water samples. Generally, increased values of $\mathrm{Ca}^{2+}, \mathrm{Mg}^{2+}, \mathrm{Na}^{+}, \mathrm{K}^{+}, \mathrm{HCO}_{3}^{-}, \mathrm{K}^{+}$and $\mathrm{Cl}^{-}$occur in the groundwater from deeper artesian wells, as a result of the longer retention time of water underground and its interaction with the geological environment. Dominant groundwater in Prilep field is water from the hydrocarbonate class ( $\mathrm{HCO}_{3}^{-}$), calcium group (Ca), the first type of water. Groundwater from the shallow wells shows an increased content of $\mathrm{K}^{+}, \mathrm{NO}_{3}^{3-}$ and $\mathrm{PO}_{4}^{3-}$ which indicates water pollution from fertilization of the cultivated areas, livestock farms as well as communal wastewater. Although hydrochemical data is obtained on the basis of water samples taken only once, they provide an indicative insight into the hydrochemical composition of the water.
\end{abstract}

Keywords:

groundwater, Piper diagram, Chadha's diagram, spatial distribution, Pelagonia Valley, Macedonia.

\section{Introduction}

Pelagonia Valley (which includes the investigated area) is located in the southwestern part of Republic of Macedonia (see Figure 1). It covers an area of about $4000 \mathrm{~km}^{2}$ and has a north-south stretch. It is the largest basin in Macedonia and represents a significant hydrogeological structure with large potential reserves of groundwater and carbon dioxide $\left(\mathrm{CO}_{2}\right)$. The Prilep part of the Pelagonia Basin, which is the subject of our research, covers its north - east parts (see Figure 1).

Groundwater in this valley is accumulated in Neogene (Miocene-Pliocene) and Quaternary unbound or poorly bound clastic sediments. According to the hydrodynamic characteristics of the level, the groundwater occurs in free-level aquifers and in aquifers with artesiansubartesian levels.

Corresponding author: Vojo Mirčovski

vojo.mircovski@ugd.edu.mk
The Pelagonia Basin has been developed on a palaeorelief of Precambrian gneisses, micaschists and granitoids from the Pelagonian massif and through various schist's and granites of Palaeozoic age.

As a result of the intensive development of urban centers, industrialization, intensive agricultural and livestock production, especially in the plane part of the investigated area and even more so within the Pelagonia Basin, the pollution of the environment in this area and the pollution of groundwater is more pronounced.

Groundwater of this valley is more intensively exploited for water supply, irrigation, and water that is packaged for drinking. Carbon dioxide, which is exploited in its southern parts at several sites, is used in the multi-purpose industry.

Since the use of groundwater is more pronounced, there is the inevitable need for monitoring its quality.

There are numerous hydrogeological studies on the area in the Republic of Macedonia that have determined the quality of groundwater. 


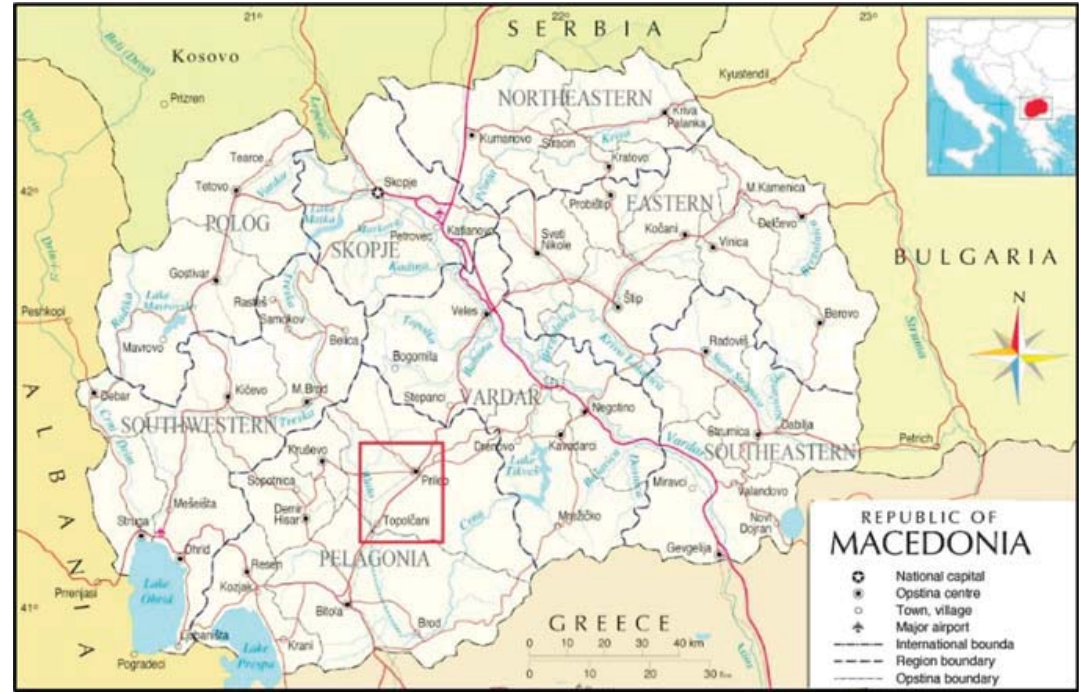

Figure 1: Geographical position of the investigated area
In the scientific project titled "Groundwater (aquifer) for solving the water supply in the Republic of Macedonia and their protection" (Djuzelkovski, 1997), provides hydrogeological and hydrochemical data for the groundwater in the territory of the Republic of Macedonia, and within that also for Pelagonia Valley.

Systematic hydrogeological investigations of Pelagonia Valley were carried out during the preparation of the Basic Hydrogeological Map of the Republic of Macedonia in the size of 1: 100000 for the sheets of Bitola, Lerin and Kruševo (Ilijoski et al., 1992-1999, 2009). Within this research, the chemical composition of groundwater was also examined.

Groundwater quality as a source for irrigation in Strumica Valley, Republic of Macedonia was studied by (Kovačević, et al., 2015). The quality of groundwater was investigated for possible agricultural pollution.

Hydrochemical investigations of groundwater in Strumica Valley from the aspect of its pollution from mining and agricultural activities were carried out by (Boev et el., 2016). With these investigations, they found that the chemistry of groundwater in Strumica Valley was predominantly influenced by the geology, and only some minor additional anthropogenic effects were recorded.

The content of some macro, micro and trace elements in some natural waters from Eastern and Southeastern Macedonia were analyzed by (Šijakova-Ivanova, 2015).

Research for determining the quality of the underground for the Prilep and Bitola part of the Pelagonia Basin was performed by (Mirčovski et al., 2014 and 2015).

Groundwater types were used by many researchers in their studies to understand the controlling factors of the water chemistry (Aris et al., 2009; Martos et al., 2002; Mondal, 2010; Rajesh et al., 2011; Ramesh and Elango, 2011).
Interpretation of groundwater chemistry using Piper and Chadha's diagrams, as a comparative study from the Perambalur Taluk area in India was made by (Kumar Sajil, 2013). Through these studies, they determined that with both methods, the dominant type of water is $\mathrm{Ca}-\mathrm{Mg}-\mathrm{Cl}$ type with a slight variation in the $\mathrm{Na}-\mathrm{Cl}$ type of water.

The hydrogeological and hydrogeochemical features of the wider area of Eastern Slavonia, the regional source Sikirevci was investigated (Kopić et al., 2016). These investigations found that underground water which flows from the wells from the wider environment of the regional source contains iron, manganese, natural ammonia and arsenic in concentrations exceeding the maximum permissible concentrations of potable water, and conclude that the elevated values of the said parameters are a consequence of the mineral composition and reductive conditions in the aquatic environment.

In order to contribute to the determination of the hydrochemical characteristics of groundwater from the investigated area during the summer period in August 2013, 12 samples of groundwater from exploitation wells were taken. Although the monitoring of groundwater quality should be done in several seasons, we still believe that our single-sampling surveys provide indicative data on the hydrochemical character of groundwater from the investigated area.

\section{Geology}

According to tectonic regionalization of the Republic of Macedonia, Prilep's part of Pelagonia Valley (Prilep Basin) falls within the Pelagonia horst anticlinorium (Arsovski, 1997).

Pelagonia Valley (which includes the investigated area), is a tectonic graben structure whose formation began at the end of Middle Miocene (Dumurdzhanov et al., 2002). 
Figure 2: Location of the wells from which the samples were taken

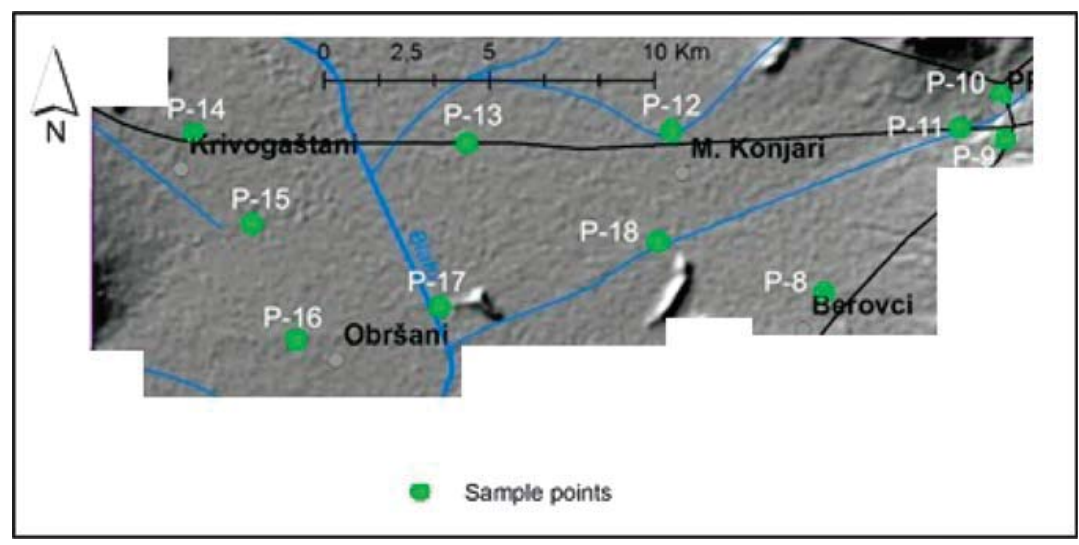

The Prilep Neogene Basin is composed of Quaternary and Pliocene sediments (Dumurdzanov et al., 1979; (Rakičević et al., 1965). The Quaternary sediments completely cover the Pliocene sediments.

Pliocene lake sediments are represented by clays, sandy gravel clays, clayey sands and gravels and layers constructed of clean sand and gravel. Over Pliocene, Quaternary sediments are represented by proluvial and alluvial sediments.

Proluvial sediments occur in peripheral parts of the basin and they are constructed of coarse clastic, poorly processed unsorted material consisting of sand, gravel and clay with the occurrence of large males that come from surrounding parent rocks.

Alluvial sediments cover the rest of the basin and they are built by well sorted coarse clastic material represented by sands and gravels with localized occurrences of clays and dust.

The wider region of the investigated area is basically composed of Precambrian and Palaeozoic metamorphic rocks that have been developed in peripheral mountain massifs and at the base of the Neogene lake sediments.

Precambrian metamorphic rocks are represented with a broad variety of gneiss, mica, granodiorites, granites, calcite marbles and dolomite marbles.

Palaeozoic rocks are represented mainly with: quartz - sericite and graphite schist, meta sandstones and quartzite, and epidotic- chlorite amphibolite schist.

\section{Hydrogeology}

The Prilep Neogene Basin from a hydrogeological aspect can be treated as a hydrogeological unit, and it has a region that is covered in water-permeable rocks along with a region of waterproof (mostly waterproof) rocks (Iliovski et al., 2010).

The collection of water-permeable rocks fall into the group of not bound clastic sedimentary rocks, represented by proluvial, alluvial and Pliocene sediments. These rocks have intergranular porosity and formed a boundary type of aquifers. These sediments cover the entire
Neogene basin and part of the bases of the peripheral mountain ranges.

In water, impenetrable rocks lie among layers of clay and dust within the Neogene sediments in the basin, which do not occur on the surface of the ground. These water impermeable layers contain aquifers under pressure (subartesian and artesian aquifers).

Depending on the hydrodynamic level of the aquifers, within the basin phreatic types of aquifers (aquifers with free level of groundwater) and artesian and subartesian aquifers (aquifers with pressure level groundwater) can be found.

\section{Methods}

In order to analyse hydrochemical characteristics of the groundwater from the Prilep part of Pelagonia Valley, samples were taken from 12 wells. The locations of the wells that were sampled are shown in Figure 2.

Samples were taken once during August 2013. The analyses of the samples of underground water were conducted in the laboratory of the University of Goce Delchev in Shtip.

The values of $\mathrm{pH}$ were determined with a field digital $\mathrm{pH}$ meter, while cations were determined by inductively coupled plasma-atomic emission spectrometry (ICP AES). For the determination of the anions, standard EPA methods were used (gravimetric - TDS, volumetric - $\mathrm{Cl}^{-}$, spectrophotometric - $\mathrm{NO}_{3}^{-}, \mathrm{NO}_{2-}^{-}, \mathrm{NH}^{4+}$ and turbidimetric - $\mathrm{SO}_{4}^{2-}$ with the spectrophotometer 6715 UV / VIS, Jenway). The obtained results are shown in Table 1.

On the basis of the obtained results (see Table 1) the maps with spatial distribution of the elements were prepared using the IDW (Inverse Distance Weighting) method for map generation (Geographic Information System software (GIS) ESRI® ArcGis ${ }^{\text {TM }} 9.2$ and its extension Geostatistical Analyst). Spatial distribution maps were constructed according to the coordinates and sample content of each analysed sample.

For interpretation of the chemical analysis, two grapho-analytical methods were used. The data is pre- 
Table 1: Chemical analysis of groundwater - the Prilep part of Pelagonia Valley

\begin{tabular}{|c|c|c|c|c|c|c|c|c|}
\hline Parameter & $\mathrm{Ca}$ & $\mathrm{Mg}$ & $\mathrm{Na}$ & $\mathrm{K}$ & $\mathrm{Sr}$ & $\mathrm{Ba}$ & $\mathrm{B}$ & $\mathrm{pH}$ \\
\hline unit & $(\mathrm{mg} / \mathrm{l})$ & $(\mathrm{mg} / \mathrm{l})$ & $(\mathrm{mg} / \mathrm{l})$ & $(\mathrm{mg} / \mathrm{l})$ & $(\mathrm{mg} / \mathrm{l})$ & $(\mathrm{mg} / \mathrm{l})$ & $(\mathrm{mg} / \mathrm{l})$ & \\
\hline Macedonian standard & - & - & 200 & 12 & 1 & 0.7 & 1.0 & $6.5-9.5$ \\
\hline$P-7$ & 22.7 & 13.4 & 11.3 & 4.9 & 0.380 & 0.167 & 0.004 & 8.5 \\
\hline$P-8$ & 36.7 & 12.6 & 31.7 & 3.5 & 0.238 & 0.025 & 0.189 & 8.6 \\
\hline$P-9$ & 20.8 & 5.8 & 15.7 & 2.1 & 0.086 & 0.023 & 0.004 & 8.1 \\
\hline$P-10$ & 78.9 & 21.7 & 23.4 & 5.8 & 0.261 & 0.035 & 0.010 & 8.5 \\
\hline $\mathrm{P}-11$ & 88.1 & 26.4 & 24.6 & 4.9 & 0.331 & 0.046 & 0.019 & 8.7 \\
\hline $\mathrm{P}-12$ & 58.2 & 14.9 & 27.9 & 2.3 & 0.281 & 0.064 & 0.063 & 8.7 \\
\hline $\mathrm{P}-13$ & 59.7 & 20.3 & 18.9 & 2.2 & 0.228 & 0.039 & 0.015 & 8.7 \\
\hline$P-14$ & 54.7 & 20.4 & 40.3 & 46.9 & 0.324 & 0.057 & 0.087 & 8.2 \\
\hline$P-15$ & 177.2 & 139.5 & 65.0 & 4.1 & 1.54 & 1.218 & 0.874 & 7.4 \\
\hline $\mathrm{P}-16$ & 45.4 & 5.7 & 6.4 & 2.5 & 0.099 & 0.014 & 0.013 & 8.4 \\
\hline $\mathrm{P}-17$ & 69.5 & 22.3 & 45.4 & 6.0 & 0.341 & 0.093 & 0.122 & 8.7 \\
\hline$P-18$ & 58.3 & 17.2 & 55.5 & 3.8 & 0.479 & 0.130 & 0.425 & 8.6 \\
\hline Parameter & $\mathrm{HCO}_{3}^{-}$ & $\mathrm{Cl}^{-}$ & $\mathrm{SO}_{4}{ }^{2-}$ & $\mathrm{NO}^{3-}$ & $\mathrm{PO}_{4}{ }^{3-}$ & $\mathrm{NO}^{2-}$ & $\mathrm{NH}^{4+}$ & TDS fil \\
\hline unit & $(\mathrm{mg} / \mathrm{l})$ & $(\mathrm{mg} / \mathrm{l})$ & $(\mathrm{mg} / \mathrm{l})$ & $(\mathrm{mg} / \mathrm{l})$ & $(\mathrm{mg} / \mathrm{l})$ & $(\mathrm{mg} / \mathrm{l})$ & $(\mathrm{mg} / \mathrm{l})$ & $(\mathrm{mg} / \mathrm{l})$ \\
\hline Macedonian standard & $>30$ & 250 & 250 & 50 & 0.3 & - & 0.1 & $<1000$ \\
\hline$P-7$ & 42.3 & 54.5 & 24.9 & 28 & 0.13 & $<0.01$ & $<0.02$ & 229 \\
\hline$P-8$ & 99.7 & 89.0 & 21.2 & 19 & 0.23 & $<0.01$ & 0.028 & 291 \\
\hline P - 9 & 54.4 & 46.1 & 7.2 & 19 & 0.089 & $<0.01$ & $<0.02$ & 182 \\
\hline$P-10$ & 178.2 & 127.8 & 33.1 & 73 & 0.53 & $<0.01$ & $<0.02$ & 529 \\
\hline$P-11$ & 169.1 & 137.2 & 32.8 & 28 & 0.16 & $<0.01$ & 0.020 & 468 \\
\hline$P-12$ & 169.1 & 62.8 & 20.5 & 7.0 & 0.15 & $<0.01$ & 0.048 & 379 \\
\hline$P-13$ & 145.0 & 78.5 & 11.1 & 55 & 0.14 & $<0.01$ & $<0.02$ & 330 \\
\hline P - 14 & 108.7 & 120.4 & 45.4 & 181 & 3.6 & $<0.01$ & 0.054 & 436 \\
\hline$P-15$ & 767.1 & 122.5 & 18.2 & 14 & 0.47 & $<0.01$ & 0.40 & 1383 \\
\hline $\mathrm{P}-16$ & 78.5 & 30.4 & 19.1 & 4.9 & 0.044 & $<0.01$ & 0.028 & 167 \\
\hline $\mathrm{P}-17$ & 151.0 & 119.4 & 32.4 & 83.7 & 0.63 & $<0.01$ & 0.036 & 425 \\
\hline $\mathrm{P}-18$ & 154.0 & 136.1 & 23.8 & 0.52 & 0.13 & $<0.01$ & $<0.02$ & 385 \\
\hline
\end{tabular}

sented on a trilinear Piper diagram (Piper, 1944). The major cations and anions are plotted in milligram per litre $\left(\mathrm{mg} \cdot \mathrm{L}^{-1}\right)$, in each triangle, then the plotting from triangular fields was extended further into the central diamond field. A Piper diagram was used to identify the water composition type and rock types of the aquifer.

In the Chadha diagram (Chadha, 1999), the difference in milliequivalent percentage between alkaline earth metals $(\mathrm{Ca}+\mathrm{Mg})$ and alkali metals $(\mathrm{Na}+\mathrm{K})$, expressed as a percentage of reacting values, is plotted on the $\mathrm{X}$-axis, and the difference in milliequivalent percentage between weak acidic anions (carbonate + bicarbonate) and strong acidic anions (chloride + sulphate) is plotted on the Y-axis. The milliequivalent percentage differences between alkaline earths and alkali metals, and between weak acidic anions and strong acidic anions, are plotted in one of the four possible sub-fields of the proposed diagram. The square or rectangular field describes the overall character of the water.

\section{Results and discussion}

The wells from which the groundwater samples were taken are divided into three groups: wells with free level with a depth of up to $10 \mathrm{~m}$ (P14, P17), wells with free level with a depth of up to $100 \mathrm{~m}$ (P8, P9, P10, P11, P16) and artesian wells (P7, P12, P13, P15, P18).

Two analysed water samples from the first group showed different properties. Major ions in the water sample P14 were dominantly $\mathrm{Ca}^{2+}>\mathrm{K}^{+}>\mathrm{Na}^{+}$for the cations and $\mathrm{Cl}^{-}>\mathrm{HCO}_{3}^{-}>\mathrm{SO}_{4}^{2-}$ for the anions, whereas the major ions in the water sample $\mathrm{P} 17$ were dominantly $\mathrm{Ca}^{2+}>\mathrm{Na}^{+}>\mathrm{Mg}^{2+}$ for the cations and $\mathrm{HCO}_{3}{ }^{-}>\mathrm{Cl}^{-}>\mathrm{SO}_{4}{ }^{2-}$ for the anions. $\mathrm{Ca}^{2+}>\mathrm{Na}^{+}>\mathrm{Mg}^{2+}$ for the cations and $\mathrm{HCO}_{3}{ }^{-}>\mathrm{Cl}^{-}>\mathrm{SO}_{4}{ }^{2-}$ for the anions were dominantly dissolved ions in the water samples of the second group. Mainly, $\mathrm{Ca}^{2+}>\mathrm{Mg}^{2+}>\mathrm{Na}^{+}$for the cations and $\mathrm{HCO}_{3}^{-}>$ $\mathrm{Cl}^{-}>\mathrm{SO}_{4}^{2-}$ for the anions were dominantly dissolved ions in the majority water samples of the third group. 


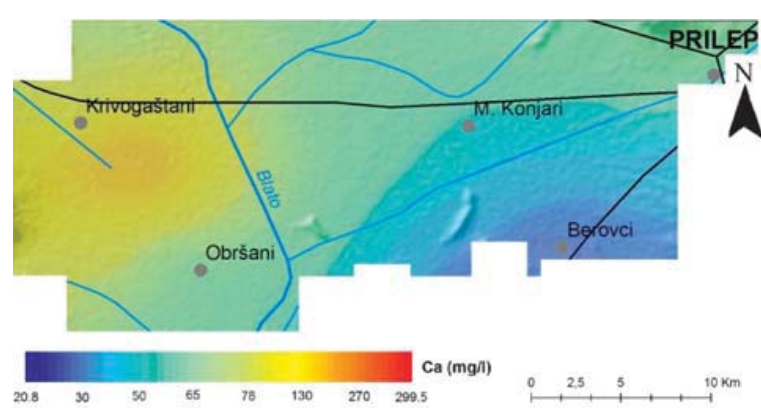

Figure 3: Inverse Distance Weighting map of Ca

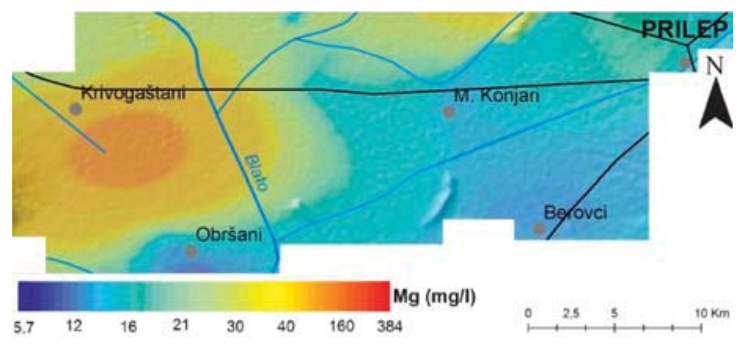

Figure 4: Inverse Distance Weighting map of Mg

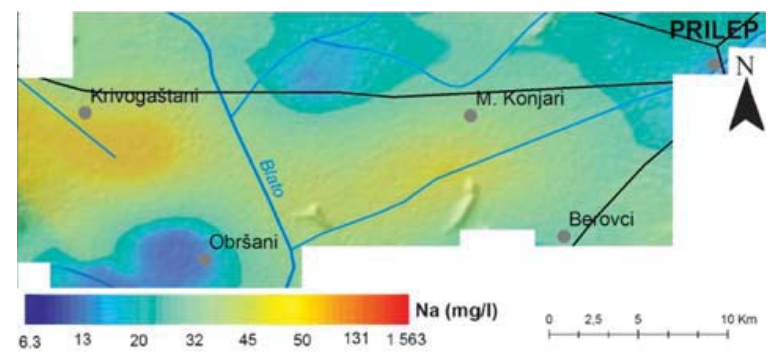

Figure 5: Inverse Distance Weighting map of $\mathrm{Na}$

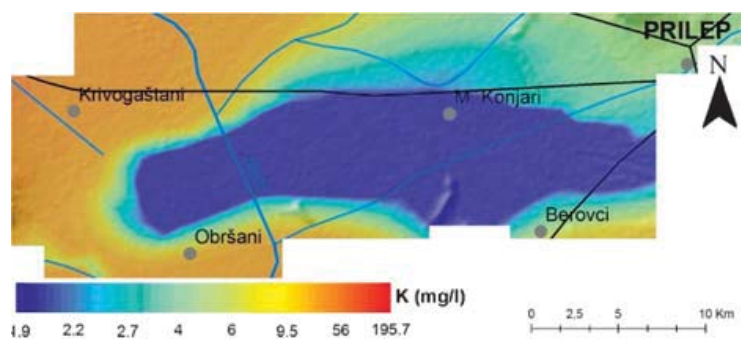

Figure 6: Inverse Distance Weighting map of K

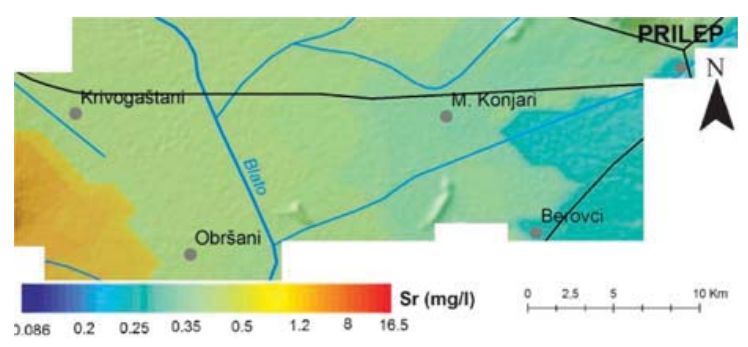

Figure 7: Inverse Distance Weighting map of $\mathrm{Sr}$

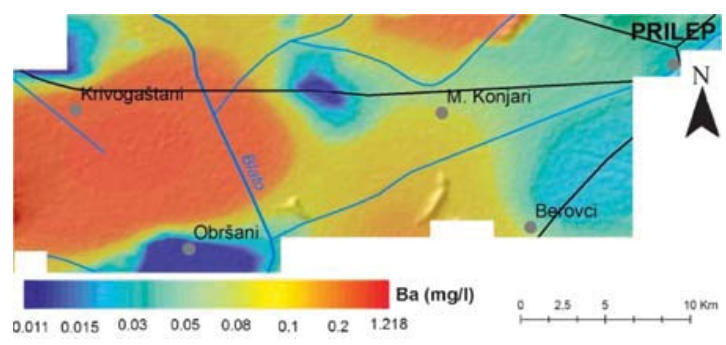

Figure 8: Inverse Distance Weighting map of $\mathrm{Ba}$

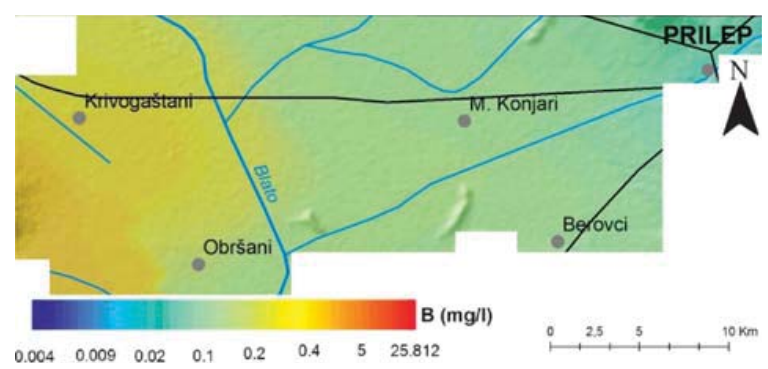

Figure 9: Inverse Distance Weighting map of B

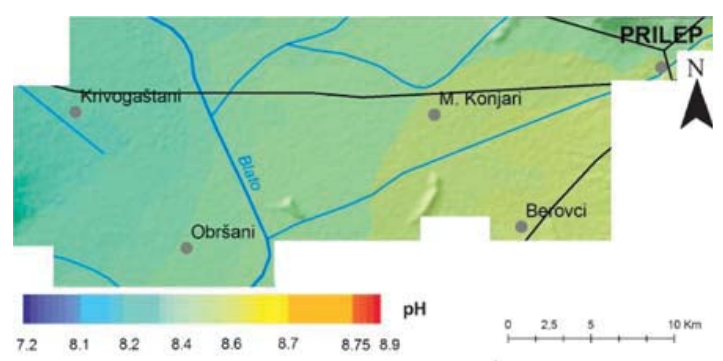

Figure 10: Inverse Distance Weighting map of $\mathrm{pH}$

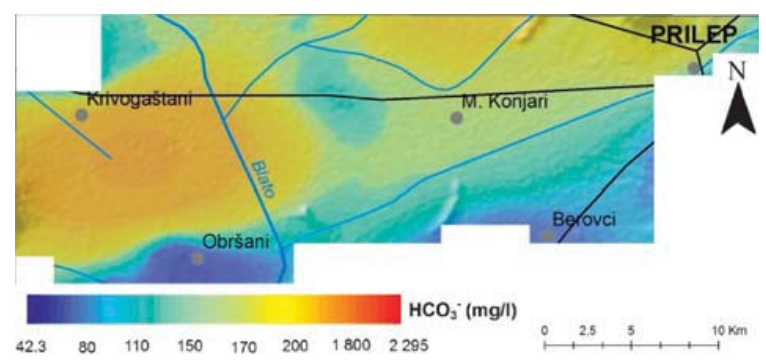

Figure 11: Inverse Distance Weighting map of $\mathrm{HCO}_{3}$

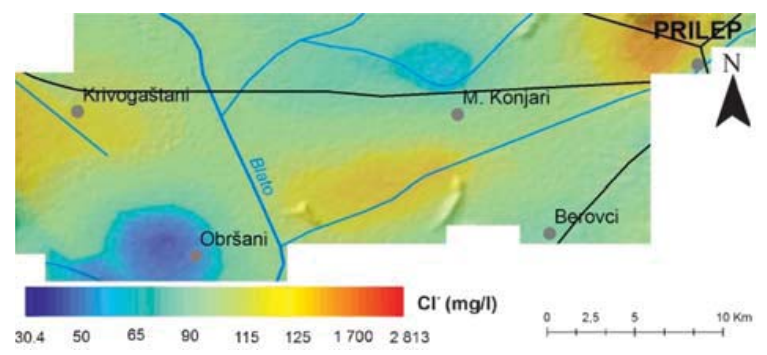

Figure 12: Inverse Distance Weighting map of $\mathrm{Cl}^{-}$ 


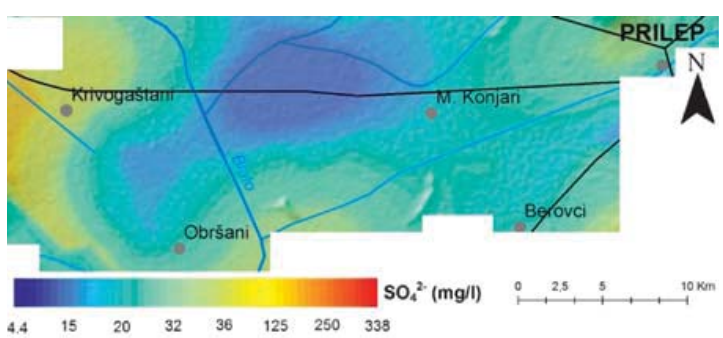

Figure 13: Inverse Distance Weighting map of $\mathrm{SO}_{4}{ }^{2-}$

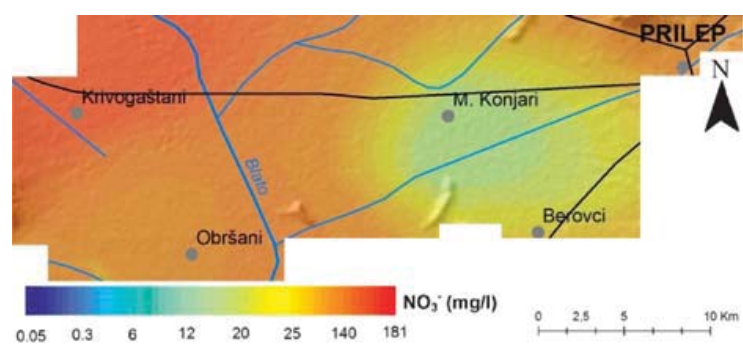

Figure 14: Inverse Distance Weighting map of $\mathrm{NO}_{3}$

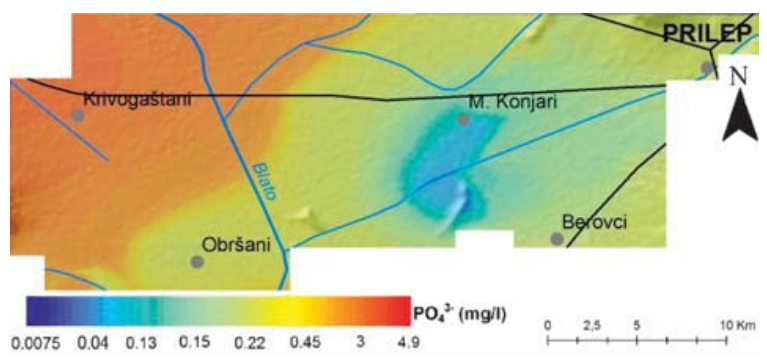

Figure 15: Inverse Distance Weighting map of $\mathrm{PO}_{4}{ }^{3-}$

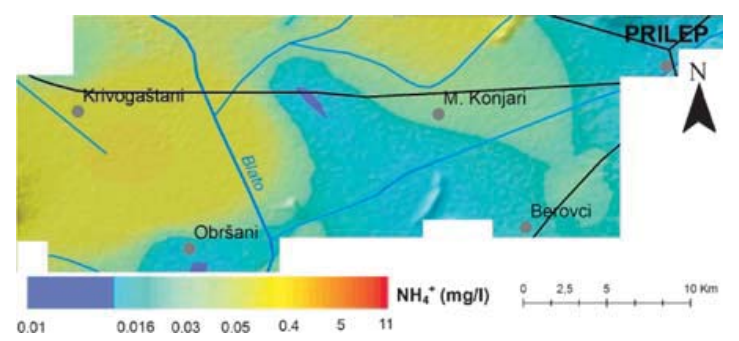

Figure 16: Inverse Distance Weighting map of $\mathrm{NH}^{4+}$

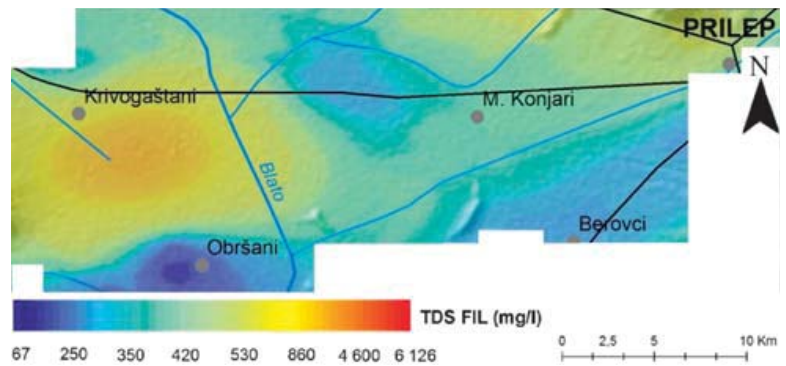

Figure 17: Inverse Distance Weighting map of TDS FIL

Major ions in the water sample P18 were dominantly $\mathrm{Na}^{+}>\mathrm{Ca}^{2+}>\mathrm{Mg}^{2+}$ for the cations and $\mathrm{HCO}_{3}>\mathrm{Cl}^{-}>\mathrm{SO}_{4}{ }^{2-}$ for the anions, whereas the major ions in the water sample $\mathrm{P} 12$ were dominantly $\mathrm{Ca}^{2+}>\mathrm{Na}^{+}>\mathrm{Mg}^{2+}$ for the cations and $\mathrm{HCO}_{3}^{-}>\mathrm{Cl}^{-}>\mathrm{SO}_{4}^{2-}$ for the anions.

In order to determine the quality of groundwater, the contents of the analyzed parameters have been compared to Macedonian standards for the quality of drinking water (Official Gazette of Republic of Macedonia, Water-safety regulation book, Nr. 46/2008 (Table 1).

Table 2: Classification of groundwater from the Prilep part of Pelagonia Valley according to Alekin

\begin{tabular}{|l|c|c|c|l|}
\hline Mark on the well & Depth of well $(\mathrm{m})$ & $\begin{array}{c}\text { Hydrochemical } \\
\text { class of water }\end{array}$ & $\begin{array}{c}\text { Hydrochemical } \\
\text { group of water }\end{array}$ & Hydrochemical type of water \\
\hline WELLS WITH FREE LEVEL WITH DEPTH TO $10 \mathrm{~m}$ & $\mathrm{Na}$ & First type of water $\mathrm{HCO}_{3^{-}}>\mathrm{Ca}^{2+}+\mathrm{Mg}^{2+}$ \\
\hline P-14 & 8 & $\mathrm{Cl}^{-}$ & $\mathrm{Ca}$ & First type of water $\mathrm{HCO}_{3^{-}}>\mathrm{Ca}^{2+}+\mathrm{Mg}^{2+}$ \\
\hline P-17 & 9 & $\mathrm{HCO}_{3}^{-}$ & $\mathrm{Ca}$ & First type of water $\mathrm{HCO}_{3^{-}}>\mathrm{Ca}^{2+}+\mathrm{Mg}^{2+}$ \\
\hline WELLS WITH FREE LEVEL WITH DEPTH TO $100 \mathrm{~m}$ & $\mathrm{Ca}$ & First type of water $\mathrm{HCO}_{3^{-}}>\mathrm{Ca}^{2+}+\mathrm{Mg}^{2+}$ \\
\hline P-7 & 45 & $\mathrm{Cl}^{-}$ & $\mathrm{Ca}$ & First type of water $\mathrm{HCO}_{3^{-}}>\mathrm{Ca}^{2+}+\mathrm{Mg}^{2+}$ \\
\hline P-8 & 55 & $\mathrm{HCO}_{3}^{-}$ & $\mathrm{Ca}$ & First type of water $\mathrm{HCO}_{3^{-}}>\mathrm{Ca}^{2+}+\mathrm{Mg}^{2+}$ \\
\hline P-9 & 85 & $\mathrm{HCO}_{3}^{-}$ & $\mathrm{Ca}$ & First type of water $\mathrm{HCO}_{3^{-}}>\mathrm{Ca}^{2+}+\mathrm{Mg}^{2+}$ \\
\hline P-10 & 65 & $\mathrm{HCO}_{3}^{-}$ & $\mathrm{Ca}$ & First type of water $\mathrm{HCO}_{3^{-}}>\mathrm{Ca}^{2+}+\mathrm{Mg}^{2+}$ \\
\hline P-11 & 65 & $\mathrm{HCO}_{3}^{-}$ & $\mathrm{Ca}$ & First type of water $\mathrm{HCO}_{3^{-}}>\mathrm{Ca}^{2+}+\mathrm{Mg}^{2+}$ \\
\hline P-16 & 35 & $\mathrm{HCO}_{3}^{-}$ & $\mathrm{Ca}$ & First type of water $\mathrm{HCO}_{3^{-}}>\mathrm{Ca}^{2+}+\mathrm{Mg}^{2+}$ \\
\hline WELLS WITH ARTESIAN - SUBARTESIAN $\mathrm{LEVEL}^{-}$ & $\mathrm{HCO}_{3}^{-}$ & $\mathrm{Ca}$ & First type of water $\mathrm{HCO}_{3^{-}}>\mathrm{Ca}^{2+}+\mathrm{Mg}^{2+}$ \\
\hline P-12 & 85 & $\mathrm{HCO}_{3}^{-}$ & $\mathrm{Na}$ & First type of water $\mathrm{HCO}_{3^{-}}>\mathrm{Ca}^{2+}+\mathrm{Mg}^{2+}$ \\
\hline P-13 & 135 & $\mathrm{HCO}_{3}^{-}$ &
\end{tabular}


In some wells, as can be seen in Table 1, there is an increase in the content of some components compared with the maximum allowable concentrations (according to the Macedonian standard).

All wells with a depth of up to $10 \mathrm{~m}$ (P-14, P-17) and only one water sample of wells with a depth of up to 100 $\mathrm{m}(\mathrm{P}-10)$ show an increased content of $\mathrm{NO}_{3}{ }^{-}$and $\mathrm{PO}_{4}^{3-}$ and well $\mathrm{P}-4$ has an increase of the contents of $\mathrm{K}^{+}$. Increased values of these components in the groundwater in relation to the Macedonian standards, suggest anthropogenic pollution with municipal wastewater, wastewater from farms and artificial fertilizers and pesticides.

From the maps, it is obvious that the spatial distribution of $\mathrm{K}^{+}, \mathrm{NO}_{3}{ }^{-}$and $\mathrm{PO}_{4}{ }^{3-}$ (see Figures 6, 14 and 15) are increased in content in the shallow wells P-14 and P-17 which occur around Krivogaštani and Obršani. On these localities, intensive agricultural activity has been performed and the emergence of $\mathrm{K}^{+}, \mathrm{NO}_{3}^{-}$and $\mathrm{PO}_{4}^{3-}$ in

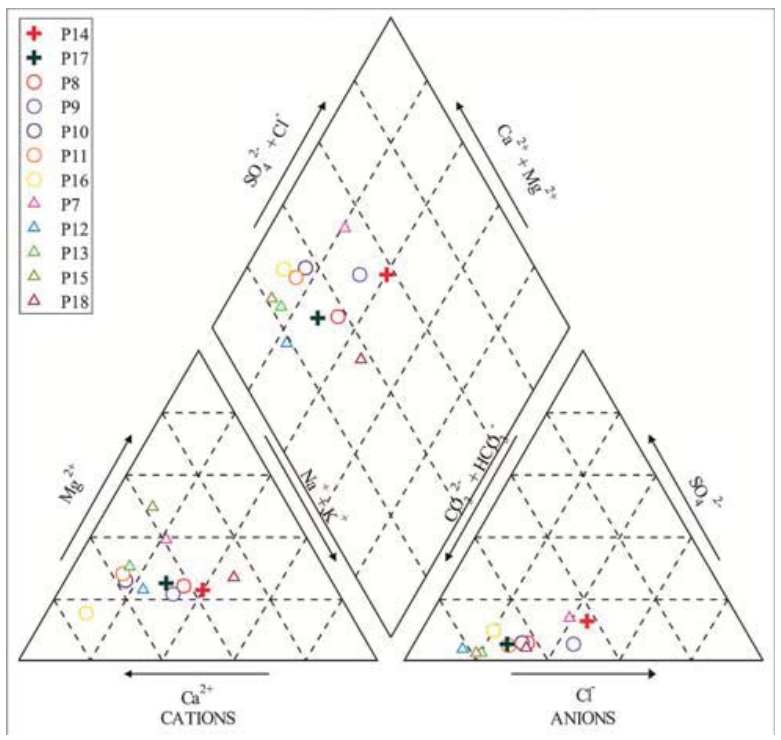

Figure 18: Piper diagram groundwater can be associated with the fertilization of agricultural areas with fertilizers which contain $\mathrm{K}^{+}, \mathrm{NO}_{3}^{-}$ and $\mathrm{PO}_{4}{ }^{3-}$.

According to the $\mathrm{pH}$ value, water from all the wells is within the Macedonian standard and belong to the group of weakly basic - basic water ( $\mathrm{pH} 7,5$ - 9.5).

According to the content of TDS, water from all the wells, with the exclusion of the artesian well P-15, belong to the group of slightly mineralized - freshwater and are included in the Macedonian standards of drinking water.

For the investigated area, maps have been made which show the spatial distribution of the content of the analyzed hydrochemical components shown in Figures 3 -17.

Determination of the hydrochemical type of water was made according to the classification of (Alekin, 1936), which has been used for the contents of the main cations and anions.

According to this classification, Table 2 shows that the dominant groundwater in Prilep field, in all three types of wells, is water from the hydrocarbonate class $\left(\mathrm{HCO}_{3}^{-}\right)$, calcium group $(\mathrm{Ca})$, the first type of water. This type of water occurs as a result of the dissolution of carbonate minerals in the geological environments through which the groundwater moves. Exceptions were made only for the P-14 well where the water falls into the chloride class $\left(\mathrm{Cl}^{-}\right)$sodium group $(\mathrm{Na})$, the first type of water, the P-7 well in which the water falls into the chloride class $\left(\mathrm{Cl}^{-}\right)$group calcium $(\mathrm{Ca})$, the first type of water and the P-18 well in which the water falls into the hydrocarbonate class $\left(\mathrm{HCO}_{3^{-}}\right)$, sodium group $(\mathrm{Na})$, the first type of water. The sodium - hydrocarbon - chloride type of water $\left(\mathrm{Na}-\mathrm{HCO}_{3^{-}}-\mathrm{Cl}^{-}\right)$occurs as a result of the interaction of groundwater with the magmatic, metamorphic and sedimentary rocks containing sodium feldspar, feldspatoides, halit and other minerals containing sodium and chlorine.

Cation and anion concentrations are plotted on the Piper diagram (see Figure 18). Almost all water samples

Figure 19: Chadha's diagram

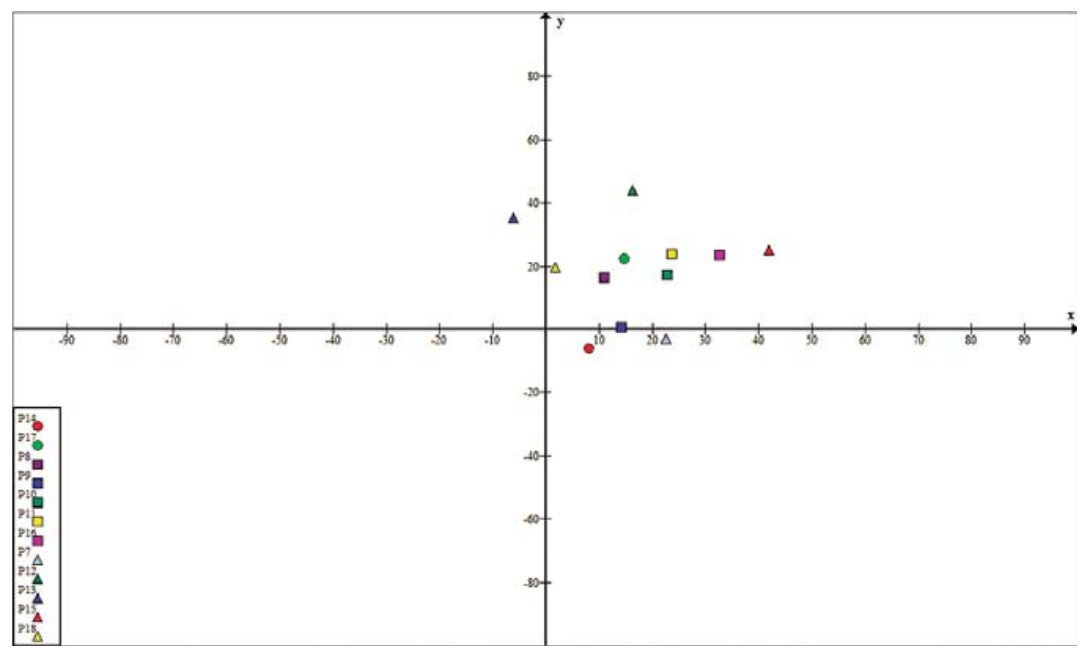

The Mining-Geology-Petroleum Engineering Bulletin and the authors @, 2018, pp. 111-119, DOI: 10.17794/rgn.2018.3.11 
are plotted near the left corner of the diamond which showed that the water is rich in $\mathrm{Ca}^{2+}, \mathrm{Mg}^{2+}$ and $\mathrm{HCO}_{3}^{-}$, and is the region of water of temporary hardness.

For a better understanding of the hydrochemistry and comparing the water types, Chadha's diagram was plotted (see Figure 19).

A majority of the samples are plotted in the 5th subfield, i.e. alkaline earths and weak acidic anions exceed both alkali metals and strong acidic anions, respectively. Such water has temporary hardness.

Two water samples (P14 and P7) fall in the 6th subfield. This indicates that alkaline earths exceed alkali metals and strong acidic anions exceed weak acidic anions. These water samples had permanent hardness, and do not deposit residual sodium carbonate in irrigation use.

One water sample from the artesian well (P13) falls in the 8th sub-field of Chadha's diagram. This indicates that alkali metals exceed alkaline earths and weak acidic anions exceed strong acidic anions. Such waters deposit residual sodium carbonate in irrigation use and cause foaming problems. One water sample (P9) falls in the 1 st sub-field. The alkaline earths exceed alkali metals.

\section{Conclusions}

Hydrochemical investigations of groundwater from the Prilep part of Pelagonia Valley are carried out with a onetime sampling of exploitation wells. The results show that groundwater from this area has different chemical compositions.

According to Alekin's classification of the dominant groundwater in Prilep field, all three types of wells contain water from the hydrocarbonate class $\left(\mathrm{HCO}_{3^{-}}\right)$, calcium group $(\mathrm{Ca})$, the first type of water. Exceptions were registered in three wells: the $\mathrm{P}-14$ well, where the water falls into the chloride class $\left(\mathrm{Cl}^{-}\right)$sodium group $(\mathrm{Na})$, the first type of water; the P-7 well in which the water falls into the chloride class $\left(\mathrm{Cl}^{-}\right)$group calcium $(\mathrm{Ca})$, the first type of water, and the P-18 well in which the water falls into hydrocarbonate class $\left(\mathrm{HCO}_{3^{-}}\right)$, sodium group $(\mathrm{Na})$, the first type of water.

In the Piper diagrams, all water samples are plotted near the left corner of the diamond which showed that the water is rich in $\mathrm{Ca}^{2+}, \mathrm{Mg}^{2+}$ and $\mathrm{HCO}_{3}^{-}$, and is the region of water of temporary hardness. The increased content of $\mathrm{K}^{+}, \mathrm{NO}_{3}^{-}$, and $\mathrm{PO}_{4}{ }^{3-}$ ions in relation to the Macedonian standard for drinking water in shallow wells P-14 and P-17 in the vicinity of Krivogashtani and Obrshani is of anthropogenic origin and may be associated with the fertilization of agricultural areas of these regions with fertilizers which contain $\mathrm{K}^{+}, \mathrm{NO}_{3}{ }^{-}$and $\mathrm{PO}_{4}{ }^{3-}$.

According to the $\mathrm{pH}$ value, water from all wells is within the Macedonian standard and belongs to the group of weakly basic - basic water ( $\mathrm{pH} 7,5$ - 9.5). According to the content of TDS, water from all the wells excluding the P-15 artesian well belongs to the group of slightly mineralized - freshwater.

Hydrochemical data gives an indicative insight into the hydrochemical composition of the water. In order to obtain more precise insight into the hydrochemical characteristics of this region, groundwater samples from wells should be taken during different seasons.

\section{References}

Alekin, A., O. (1970): Principles of hydrochemistry, Gidrometeoizdat, Leningrad.

Arsovski, M., (1997): Tectonics of Macedonia. University “St. Cyril and Methodius - Skopje" - Faculty for Mining and geology - Stip.

Aris, A., Z., Abdullah, M., H., Kim, K.,W., Praveena, S., M. (2009): Hydrochemical changes in a small tropical island's aquifer: Manukan Island, Sabah, Malaysia. Environ Geol., 56, 1721-1732.

Boev, I., Šorša, A., Kovačević,B., Saša Mitrev, S., Boev, B. (2016): The use of factor analysis to distinguish the influence of parent material, mining and agriculture on groundwater composition in the Strumica valley, Macedonia. Geologia Croatica, 69, 2, 245-253.

Chadha, D. K. (1999): A proposed new diagram for geochemical classification of natural waters and interpretation of chemical data. Hydrogeology Journal, 7, 431-439.

Djuzelkovski, D., (1997): Podzemni vodi (izdan) za rešavanje na vodosnabduvanjeto vo Republika Makedonija i nivna zaštita. Naučen proekt. (Groundwater (aquifer) for solving the water supply in the Republic of Macedonia and their protection. Scientific project). Institute Geohydroproject Skopje. Institute Geohydroproject - Skopje. (Institut Geohidroproekt - Skopje)

Dumurdzhanov, N., Petrov, G., Stojanova, V. (2002): Genesis of Neogene - Quaternary depression and their formation stratification characteristics of the Macedonian territory. Science project. University "St. Cyril and Methodius Skopje" - Faculty for Mining and geology - Stip

Ilijoski, Z., Lončar, I. Pešovska, S. (2010): Tolkuvač za Osnovna hidrogeološka karta na Republika Makedonija vo razmer 1:100000 za list Kruševo. Gradežen Institut Skopje. (Ilijovski, Z., Lončar, I., Pešovska, S. (2010): Interpreter of BHGM sheet Krusevo 1: 100 000. Civil engineering Institute Skopje.

Ilijoski, Z., Pešovska, S. (2009): Tolkuvač za Osnovna hidrogeološka karta na Republika Makedonija vo razmer 1:100000 za list Bitola. Gradežen Institut Skopje. (Ilijovski, Z., Pešovska, S. (2010): Interpreter of BHGM sheet Bitola 1: 100 000. Civil ingenering Institute Skopje.)

Ilijoski, Z., Pešovska, S. (2009): Tolkuvač za Osnovna hidrogeološka karta na Republika Makedonija vo razmer 1:100000 za list Lerin. Gradežen Institut Skopje. (Ilijovski, Z., Pešovska, S. (2010): Interpreter of BHGM sheet Lerin 1: 100 000. Civil engineering Institute Skopje.)

Kopić, J., Loborec, J., Nakić, Z. (2016): Hydrogeological and hydrogeochemical characteristics of a wider area of the regional well field Eastern Slavonia - Sikirevci. Rudarsko- 
geološko-naftni zbornik (The Mining-Geology-Petroleum Engineering Bulletin), 34, 47-66.

Kumar, S., P., J. (2013): Interpretation of groundwater chemistry using piper and chadha's diagrams: a comparative study from perambalur taluk. Elixir Geoscience, 54 p. 12208-12211.

Mirčovski, V., Boev, B., Efremoski, Z., Šorša, A., Dimov, G. (2015): Hydrochemical data for the ground waters in the Bitola's part of the Pelagonia Valley, Republic of Macedonia. Geologica Macedonica, 29, 1, 15-24.

Mirčovski, V., Boev B., Ristevski, P. (2014): Heavy and toxic metals in the ground water of the Prilep region from the Pelagonia valley. Geologica Macedonica, 28 (1). pp. 93-98.

Mondal, N., C., Singh, V., P., Singh, V., S,. Saxena, V,.K. (2010): Determining the interaction between groundwater and saline water through groundwater major ions chemistry. Journal of Hydrology, 388: 100-111.

Official Gazette of Republic of Macedonia (2008): Watersafety regulation book, $\mathrm{Nr}$. 46/2008.

Piper, A.M., (1944): A graphical procedure in the geochemical interpretation of water analyses. American Geophysical Union Transaction, 25, 914-923.
Rakichević, T., Stojanov R., Arsovski, M. (1965): Tumač za list Prilep [Basic Geological Map of SFRY 1:100000, Geology of the Prilep sheet - in Macedonia]. Geološki zavod, Skopje, Savezni geološki zavod, Beograd, scale 1:100 000. Geological Institute Skopje.

Rajesh, R., Brindha, K., Murugan, R., Elango, L. (2010): Influence of hydrogeochemical processes on temporal changes in groundwater quality in a part of Nalgonda district, Andhra Pradesh, India. Environ Earth Sci, DOI $10.1007 / \mathrm{s}, 12665$ - 011-1368 - 2.

Ramesh, K., Elango, L. (2011): Groundwater quality and its suitability for domestic and agricultural use in Tondiar river basin, Tamil Nadu, India Environ Monit Assess, DOI 10.1007/s10661- 011-2231-3.

Sánchez-Martos, F., Pulido-Bosch, A., Molina-Sánchez, L. Vallejos-Izquierdo. (2002): Identification of the origin of salinization in groundwater using minor ions (Lower Andarax, Southeast Spain). Science of The Total Environment. 297, 43-58.

Šijakova-Ivanova, T., Ambarkova, V. (2015): Geochemical assessment of some natural waters from eastern and southeastern Macedonia. Geologica Macedonica, 29, 1, 5-14.

\section{SAŽETAK}

\section{Hidrokemijska svojstva podzemnih voda iz prilepskoga dijela Pelagonijske doline - Republika Makedonija}

U radu su prikazani rezultati hidrokemijskih istraživanja podzemnih voda iz prilepskoga dijela Pelagonijske doline Republika Makedonija. Ta istraživanja provedena su analizom 12 uzoraka podzemnih voda, uzetih iz iskorištavanih zdenaca. Uzorci su uzimani jednokratno tijekom kolovoza 2013. Vrijednosti pH određene su digitalnim terenskim pH mjeračem, dok su kationi određeni pomoću induktivno spregnute atomske emisijske spektrometrije (ICP-AES). Za određivanje aniona upotrijebljene su standardne EPA metode (gravimetrijski - TDS, volumetrijski - $\mathrm{Cl}^{-}$, spektrofotometrijski $-\mathrm{NO}_{3}^{-}, \mathrm{NO}^{2-}, \mathrm{NH}^{4+} \mathrm{i}$ turbidimetrijski - $\mathrm{SO}_{4}^{2-}$ sa spektrofotometrom $6715 \mathrm{UV} / \mathrm{VIS}$, Jenway). Karte s prostornom raspodjelom hidrokemijskih komponenti pripremljene su metodom inverzne udaljenosti (ESI ${ }^{\circledR}$ ArcGis ${ }^{\mathrm{TM}}$ 9.2 - Geographic Information System software, GIS, geostatistička analiza). Grafičke metode, Piperov i Chadhinov dijagram, primijenjene su kako bi se odredile hidrokemijske značajke podzemnih voda. Rezultati pokazuju kako uzorci podzemnih voda imaju različita hidrokemijska svojstva. $\mathrm{Ca}^{2+}>\mathrm{Na}^{+}>\mathrm{Mg}^{2+}$ za katione i $\mathrm{HCO}^{3-}>\mathrm{Cl}^{-}>\mathrm{SO}^{2-}$ za anione dominantno su otopljeni ioni $\mathrm{u}$ većini uzoraka vode. Općenito, povećane vrijednosti $\mathrm{Ca}^{2+}, \mathrm{Mg}^{2+}, \mathrm{Na}^{+}, \mathrm{K}^{+}, \mathrm{HCO}_{3}^{-}, \mathrm{K}^{+}$i $\mathrm{Cl}^{-}$pojavljuju se u podzemnim vodama iz dubljih arteških zdenaca, kao rezultat dužega zadržavanja vode u podzemlju i njezina međudjelovanja s geološkim okolišem. Dominantne podzemne vode na području Prilepa hidrokarbonatne su klase $\left(\mathrm{HCO}_{3}^{-}\right)$, kalcijske grupe (Ca), tj. prva vrsta vode. Podzemne vode iz plitkih zdenaca pokazuju povećani sadržaj $\mathrm{K}^{+}, \mathrm{NO}_{3}^{-}$i $\mathrm{PO}_{4}^{3-}$, što upućuje na onečišćenje voda iz gnojidbe obradivih poljoprivrednih površina, od stočnih farmi te iz komunalnih otpadnih voda. Iako su hidrokemijski podatci dobiveni na temelju jednokratnoga uzorkovanja, oni ipak daju indikativan uvid u hidrokemijski sastav vode.

Ključne riječi:

podzemne vode, Piperov dijagram, Chadhinov dijagram, prostorna raspodjela, Pelagonijska dolina, Makedonija

\section{Authors contribution:}

Vojo Mirčovski: analysis and interpretation of hydrochemical data for groundwater. Biljana Gičevski: graphical processing of the hydrohemical data of the Piper and Chadha diagram, as well as maps of the spatial distribution. Gorgi Dimov: field sampling of groundwaters, hydrogeological and geological characteristics of the terrain. 